\title{
Integrasi Pendidikan Mitigasi Dalam Konten Pembelajaran Sains Sebagai Upaya Membangun Kesadaran Mitigasi Dari Jenjang Sekolah
}

\author{
Henny Johan ${ }^{1}$, Afrizal Mayub ${ }^{2}$, Rendy Wikrama Wardana ${ }^{3}$ \\ ${ }^{123}$ Universitas Bengkulu \\ Email : hennyjohan88@gmail.com
}

Article History:
Received: Desember
2020
Revised: Juni 2021
Accepted: Juni 2021
Available online: Juni
2021

Kata Kunci: integrasi
mitigasi, kesadaran
mitigasi, konsep sains,
mitigasi.

Abstrak:
Telah dilakukan kegiatan pengabdian kepada
masyarakat dengan tujuan untuk masyarakat profesionalitas guru dalam mengintegrasikan pendidikan mitigasi melalui pembelajaran sains sebagai upaya membangun kesadaran mitigasi dari jenjang sekolah. Kegiatan ini melibatkan 50 orang guru IPA dilaksanakan pada tanggal 12 Oktober 2020 bertempat di SMP 6 seluma. Instrument yang digunakan dalam kegiatan PPM ini adalah angket untuk menjaring data persepsi guru dan penugasan mandiri. Berdasarkan hasil kegiatan diketahui bahwa guru berpendapat pendidikan mitigasi penting untuk dilakukan dalam rangka membangun kesadaran mitigasi siswa, konsep sains berkaitan erat dengan berbagai fenomena alam termasuk fenomena bencana kebumian. Konsep sains sangat potensial untuk diintegrasikan dengan pendidikan mitigasi Berdasarkan uraian diatas maka dapat disimpulkan bahwa integrasi pendidikan mitigasi sangat penting terutama untuk daerah rawan bencana alam seperti provinsi Bengkulu. Integrasi pendidikan mitigasi sangat potensial untuk dilakukan melalui pembelajaran sains mengingat karakter konsep sains yang berkaitan erat dengan berbagai fenomena alam 


\section{Pendahuluan}

Provinsi Bengkulu terletak di sisi barat pulau Sumatera. Provinsi Bengkulu memiliki dua buah pulau yang terletak di Samudera Hindia. Bengkulu merupakan salah satu provinsi yang rawan bencana alam terutama gempa bumi. Selain bencana alam kebumian, Bengkulu juga tidak luput dari bencana lainnya seperti bencana Biologis yang sedang melanda sekarang ini yaitu wabah virus Covid-19. Gambar 1 menunjukkan letak Bengkulu secara geografis yang berada di pertemuan lempeng rawan bencana kebumian terutama gempa dan tsunami.
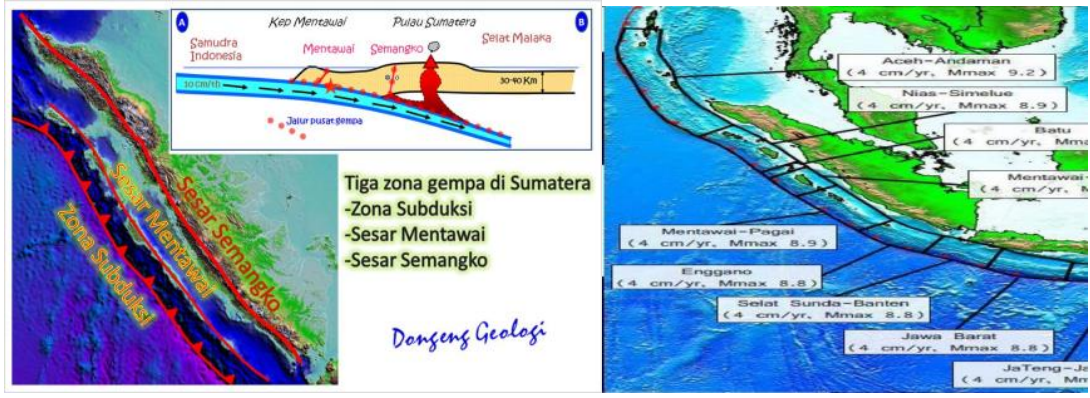

Gambar 1. Pertemuan lempeng dan posisi provinsi bengkulu yang berada pada daerah sesar mentawai yang rawan gempa dan tsunami

Pertemuan lempeng pada Gambar 1 adalah lempeng Indo-Austaralia yang membentang sepanjang pegunungan barat pulau Sumatra (Irwanto , 2015). Dari rangkaian pegunungan tersebut, di Sumatra ada gunung yang dikenal sebagai Bukit Barisan. Rangkaian pegunungan bukit barisan salah satunya melewati provinsi Bengkulu. Berdasarkan data Badan Meteorologi dan Geofisika Kabupaten Kepahiang Provinsi Bengkulu (2006) Tingkat curah hujan di daerah Bengkulu cukup tinggi yaitu rata-rata 235-280 mm/th. Febriani dkk, (2013) mengatakan bahwa curah hujan yang tinggi merupakan faktor pemicu terjadinya gerakan tanah berupa longsor dan gempa. Hal tersebut menjadi faktor pemicu terjadinya gerakan tanah (mass wasting) atau longsor (land slide) (Farda, 2010; Ibrahim, 2010). Gerakan tersebut juga dapat menyebabkan bencana alam, yaitu gempa dan tsunami bila sumber gerakan terjadi di bawah permukaan bawah laut. Pertemuan lempeng juga menjadi zona utama terjadinya bencana alam berupa gempa yang dapat menimbulkan tsunami (Sudibyakto, 2015; Subiyantoro, 2010). Berdasarkan uraian diatas maka terlihat bahwa Bengkulu termasuk pulau Enggano yang terletak di pertemuan lempeng memiliki tingkat kerawanan bencana yang ditinggi di provinsi Bengkulu

Dalam rangka meminimalisir resiko bencana maka perlu dikembangkan 
budaya siaga bencana dan kesadaran serta kesadaran akan mitigasi bencana alam. Kesadaran mitigasi bencana dan kesadaran spiritual perlu ditanamkan sedini mungkin untuk meminimalkan korban akibat bencana alam. Kesiapsiagaan bencana dan mitigasi perlu ditanamkan pada semua kalangan dari semua jenjang usia termasuk pada anak usia sekolah. Anak usia sekolah siswa merupakan salah satu populasi terbanyak banyak di provinsi Bengkulu. Berdasarkan data statistik tahun 2017 jumlah siswa di Provinsi Bengkulu didominasi oleh siswa usia sekolah sebanyak 60,3\%. Berdasarkan data dari kemendikbud (2017), Pulau Enggano memiliki 5 Sekolah Dasar, 2 Sekolah Menengah Pertama, dan 1 Sekolah Menengah Atas. Hal tersebut menjadi kekuatan dasar untuk memberikan kesadaran secara dasar terhadap masyarakat secara luas melalui pendidikan sains terintegrasi pendidikan mitigasi pada siswa usia sekolah. Selain itu siswa usia sekolah memiliki nilai karakter rasa ingin tahu dan simpatik terhadap lingkungan yang sangat tinggi (Mustari, 2011). Sekolah merupakan suatu lembaga yang berperan penting dalam agen of change dalam hal ini untuk agen of change terhadap budaya kesiapsiagaan bencana dan mitigasi yang dimulai dari usia sekolah. Anak usia sekolah ini diharapkan dapat menjadi agen of change di lingkungan sekitarnya untuk menanamkan budaya kesiapsiagaan dan mitigasi bencana alam. Membangun budaya siap siaga bencana pada anak usia sekolah bisa dilakukan melalui pendidikan mitigasi berbasis kelas melalui pembelajaran sains, berbasis budaya sekolah dengan menerapkan literasi terhadap kebencanaan dan mitigasi serta berbasis masyarakat dengan memberdayakan peran keluarga serta komunikas dalam masyarakat misalnya pemuda karangtaruna.

Salah satu cara untuk menanamkan kesadaran mitigasi dalam menghadapi bencana maka perlu mewujudkan sekolah sebagai lembaga agen of change terhadap budaya kesiapsiagaan bencana dan mitigasi. Hal ini dapat dilakukan dengan mengkolaborasikan kesadaran mitigasi bencana dan Pendidikan di sekolah melalui konten-konten sains berbasis kelas pada bahasan mengenai ilmu kebumian. Pembelajaran konsep-konsep sains dapat diintegrasikan dengan penanaman kesadaran mitigasi bencana alam kebumian, mengembangkan rasa ingin tahu pada anak, kebebasan si anak itu sendiri harus ada untuk melakukan dan melayani rasa ingin tahunya. Untuk dapat mewujudkan budaya siap siaga terhadap bencana pada siswa usia sekolah maka hal terpenting yang perlu dikembangkan adalah kompetensi Guru dalam pendidikan mitigasi. Kompetensi guru sains yang baik dalam pendidikan mitigasi dapat menghadirkan kegiatan pembelajaran sains yang mampu meningtegrasikan pembelajaran sains dan pendidikan mitigasi pada level 
pembelajaran di kelas sekaligus menjadi agen dalam mewujudkan budaya sekolah yang literasi terhadap kebencanaan dan mitigasi.

Kompetensi guru yang baik pada pembelajaran sains berorientasi pada pendidikan mitigasi dapat menghadirkan pembelajaran sains dikelas yang sekaligus mampu melibatkan kemampuan berpikir dan melatih kemampuan problem solving anak usia sekolah ketika menghadapai situasi darurat bencana akan lebih bermanfaat karena memungkinkan mereka menjadi remaja yang siap berkiprah sebagai agen of change terhadap budaya siap siaga bencana dan memberi kesempatan pada mereka untuk dapat mengeksplor kemampuan berpikir dalam menghadirkan berbagai alternative solusi yang relevan dengan situasi darurat bencana. Selain itu, hal ini juga memberi kesempatan untuk para remaja berkontribusi secara positif ditengah masyarakat dan menyiapkan mental dan moral spiritual yang lebih tangguh.

Sebagaimana diketahui bahwa pendidikan mitigasi merupakan satu langkah penting dalam menyiapkan budaya siap siaga bencana (Permana dkk, 2011). Hal ini termasuk pada anak usia sekolah dan sekolah sebagai agen of change untuk menyiapkan masyarakat tangguh bencana yang dapat melakukan prosedur mitigasi dengan tepat dan kritis. Menggalakkan pendidikan mitigasi merupakan suatu upaya untuk memberdayakan masyarakat sebagai bagian dari budaya siap siaga mitigasi bencana alam. Untuk dapat menggalakkan pendidikan mitigasi melalui pembelajaran sains tersebut maka diperlukan juga guru-guru yang memiliki kompetensi kearah pendidikan mitigasi dan kompetensi pedagogi yang mumpuni dalam membelajarkan konten-konten sains. Kompetensi-kompetensi tersebut dapat memberi peluang para guru untuk dapat mengintegrasikan pendidikan mitigasi melalui pembelajaran konten sains pada level pembelajaran kelas, selain itu mampu menjadi agen untuk mengembangkan budaya sekolah yang memiliki literasi yang baik terhadap kebencanaan dan mitigasi bencana alam. Permasalahnya adalah belum terarahkan kompetensi pedagogi dan kompetensi pada pendidikan mitigasi sehingga belum mampu menghadirkan pembelajaran sains yang terintegrasi pendidikan mitigasi pada level pembelajaran kelas.

Berdasarkan uraian diatas maka sangat diperlukan solusi yang bersifat praktis yang dapat diterapkan untuk meningkatkan kompetensi guru dalam pendidikan mitigasi melalui sebuah workshop/pelatihan pembelajaran sains yang mengintegrasikan pendidikan mitigasi sebagai upaya membangun budaya siap siaga bencana alam pada siswa sekolah di provinsi Bengkulu. 
Tujuan kegiatan pengabdian pada masyarakat ini adalah: 1) Mengintegrasikan pendidikan mitigasi pada pembelajaran sains; 2) Membuka wawasan para guru untuk menyadari pentingnya pendidikan mitigasi pada jenjang sekolah; 3) Melatih para guru untuk dapat mengintegrasikan pendidikan mitigasi melalui pembelajaran sains. Adapun manfaat kegiatan pengabdian pada masyarakat ini adalah :1) Bagi para guru, bertambahnya wawasan pada pembelajaran sains yang tidak hanya berfokus pada ranah kognitif tetapi mampu meningkatkan kesadaran mitigasi; 2) Bagi siswa, adanya variasi pembelajaran yang dapat memuka wawasan akan pentingnya mitigasi; 3) Bagi masyarakat umum, membantu terciptanya budaya siap siaga bencana dimulai dari usia sekolah; 4) Bagi institusi, melalui kegiatan ini akan meningkatkan peran Universitas Bengkulu dalam mentransformasikan ilmu pengetahuan dan teknologi di kabupaten yang ada di provinsi Bengkulu.

\section{Metode}

Pengabdian ini direnacanakan akan dilakukan di kabupaten Bengkulu Selatan. Bekerjasama dengan MGPM kabupaten Seluma. Kegiatan ini akan melibatkan guru terutama guru sains dari sekolah menengah pertama dan atau sekolah menengah atas. Pelaksanaan kegiatan pengabdian melalui workshop atau pelatihan. Kegiatan pelatihan dilakukan dengan metode ceramah, demonstrasi, diskusi dan penugasan mandiri. Adapun tahapan kegaiatan PPM yang dilakukan adalah:

1. Tahap Persiapan

Tahap persiapan dan awal dilakukan koordinasi tim terlebih dahulu dengan LPPM dan khalayak sasaran pengabdian. Kemudian dilakukan pengurusan perizinan. Selanjutnya penyusunan rencana dan jadwal kegiatan. Serta menyiapkan bahan untuk kegiatan workshop.

2. Pelaksanaan Kegiatan

1. Sosialisai jadwal dan materi kegiatan di lokasi pengabdian.

2. Workshop/bimtek yang berfokus pada penguatan kompetensi guru pada pendidikan mitigasi dengan melakukan kegiatan analisis kurikulum 13, pemetaan kompetensi dasar dan analisis konten sains untuk menggiring guru dapat membidik potensi-potensi integrasi pendidikan mitigasi melalui pembelajaran konten sains, merancang model pembelajaran integrasi mitigasi bencana. 
3. Pendampingan pembuatan tugas mandiri pembuatan matrik keterkaitan antara kompetensi dasar untuk konten sains dengan konten kebencanaan.

\section{Hasil}

Pada bagian hasil dan pembahasan dibahasa hasil pada kegiatan sesi pertama yaitu pemaparan materi dengan metode ceramah, demonstrasi, dan diskusi. Pada kegaiatan sesi ke dua, guru diminta untuk mengerjakan tugas mandiri untuk membuat matriks keterkaitan antara kompetensi dasar pada konten sains dengan konten kebencanaan. Data respon dan persepsi guru terkait pentingnya integrasi pendidikan mitigasi melalui pembelajaran sains dikumpulkan menggunakan instrument angket. Hasil rekapitulasi analisis angket persepsi tersebut dapat di lihat pada Tabel 1.

Tabel 1. Rekapitulasi persepsi guru terkait integrasi pendidikan mitigasi melalui pembelajaran sains

\begin{tabular}{|c|c|c|c|c|c|}
\hline \multirow[t]{2}{*}{ No } & \multirow[t]{2}{*}{ Aspek pernyataan di dalam angket } & \multicolumn{4}{|c|}{ Respon (\%) } \\
\hline & & SS & $\mathrm{S}$ & TS & STS \\
\hline 1 & $\begin{array}{l}\text { Provinsi Bengkulu merupakan wilayah rawan bencana } \\
\text { alam }\end{array}$ & 100 & 0 & 0 & 0 \\
\hline 2 & $\begin{array}{l}\text { Wawasan/pengetahuan terkait konten kebencanaan } \\
\text { perlu dikuasai }\end{array}$ & 92 & 8 & 0 & 0 \\
\hline 3 & $\begin{array}{l}\text { Wawasan/pengetahuan terkait tindakan mitigasi perlu } \\
\text { dikuasai }\end{array}$ & 96 & 4 & 0 & 0 \\
\hline 4 & $\begin{array}{l}\text { Wawasan/pengetahuan terkait tindakan mitigasi perlu } \\
\text { berikan mulai dari jenjang sekolah }\end{array}$ & 86 & 12 & 2 & 0 \\
\hline 5 & $\begin{array}{l}\text { Fenomena bencana dapat dijelaskan dengan konsep } \\
\text { sains }\end{array}$ & 82 & 16 & 2 & 0 \\
\hline 6 & $\begin{array}{l}\text { Adanya keterkaitan antara konten sains dengan konten } \\
\text { kebencanaan }\end{array}$ & 84 & 14 & 2 & 0 \\
\hline 7 & $\begin{array}{l}\text { Konten sains sangat potensial untuk disisipkan dengan } \\
\text { konten kebencanaan }\end{array}$ & 88 & 12 & 0 & 0 \\
\hline 8 & $\begin{array}{l}\text { Pendidikan mitigasi dapat diintegrasikan dalam } \\
\text { pembelajaran konten sains }\end{array}$ & 82 & 18 & 0 & 0 \\
\hline 9 & $\begin{array}{l}\text { Pendidikan mitigasi berbasis kelas sangat potensial } \\
\text { untuk membentuk generasi sadar mitigasi dari usia dini }\end{array}$ & 80 & 18 & 2 & 0 \\
\hline 10 & $\begin{array}{l}\text { Anak usia sekolah sangat potensial untuk menjadi agen } \\
\text { of change dalam membentuk budaya masyarakat siaga } \\
\text { bencana }\end{array}$ & 80 & 18 & 2 & 0 \\
\hline Rata & rata respon & 87 & 12 & 1 & 0 \\
\hline
\end{tabular}

Keterangan: SS (sangat setuju), S (setuju), TS (tidak setuju), STS (sangat tidak setuju) 
Berdasarkan Tabel 1 terlihat bahwa rata-rata $87 \%$ dari total peserta sangat setuju dengan semua pernyataan yang ada didalam angket persepsi yang diberikan setelah mengikuti kegiatan pelatihan yang dilakukan. Terdapat $12 \%$ dari total peserta yang memberikan respon setuju dengan semua pernyataan yang ada didalam angket persepsi. Rata-rata peserta yang memberikan respon tidak setuju pada pernyataan yang terdapat di dalam angket persepsi hanya ada sebesar $1 \%$ saja atau rata-rata hanya ada 1 orang dari 50 peserta yang memberikan pernyataan tidak setuju.

Berdasarkan Tabel 1 diketahui bahwa seluruh peserta sangat setuju bahwa provinsi Bengkulu merupakan provinsi yang sangat rawan dengan bencana alam terutama bencana alam berupa gempa bumi. Diatas $90 \%$ dari total peserta sangat setuju bahwa wawasan/pengetahuan akan konten kebencanaan dan pengetahuan mitigasi sangat penting untuk dikuasai. Rata-rata diatas $85 \%$ dari total peserta sangat setuju bahwa konten sains berhubungan dengan konten kebencanaan. Konten sains dapat menjelaskan proses terjadinyaberbagai bencana alam.

$88 \%$ peserta pelatihan sangat setuju bahwa konten sains sangat potensial untuk disisipkan dengan konten kebencanaan. $82 \%$ peserta sangat setuju bahwa pendidikan mitigasi dapat diintegrasikan dalam pembelajaran konten sains. Hal ini mengindikasikan bahwa guru sangat setuju dengan konsep integrasi pendidikan mitigasi melalui pembelajaran sains. $80 \%$ responden sangat setuju bahwa kesadaran bermitiasi perlu ditamankan sejak usia sekolah. Anak usia sekolah merupakan agen of change dalam mementuk budaya siap siaga bencana.

\section{Diskusi}

Berdasarkan Tabel 1 terlihat bahwa semua guru peserta pelatihan sangat setuju provinsi Bengkulu rawan bencana alam terutama gempa bumi. Secara geologis provinsi Bengkulu terletak di pertemuan 3 lempeng tektonik yang aktif bergerak. Zona subduksi di wilayah barat sumatera sring menjadi titik hiposentrum gempa bumi yang terjadi di provinsi Bengkulu. Berdasarkan data BMKG, frekuensi gempa bumi belakangan ini semakin meningkat seperti pada ditunjukkan oleh data pada Gambar 3. Gambar 3 menunjukkan data terkini terjadinya gempa bumi yang dapat dirasakan di wilayah provinsi Bengkulu. Frekuensi gempa yang semakin tinggi mengharuskan kita untuk memiliki budaya siap siaga bencana yang tinggi. Pendidikan mitigasi menjadi sangat penting bagi masyarakat yang tinggal di daerah rawan bencana seperti di provinsi Bengkulu. 


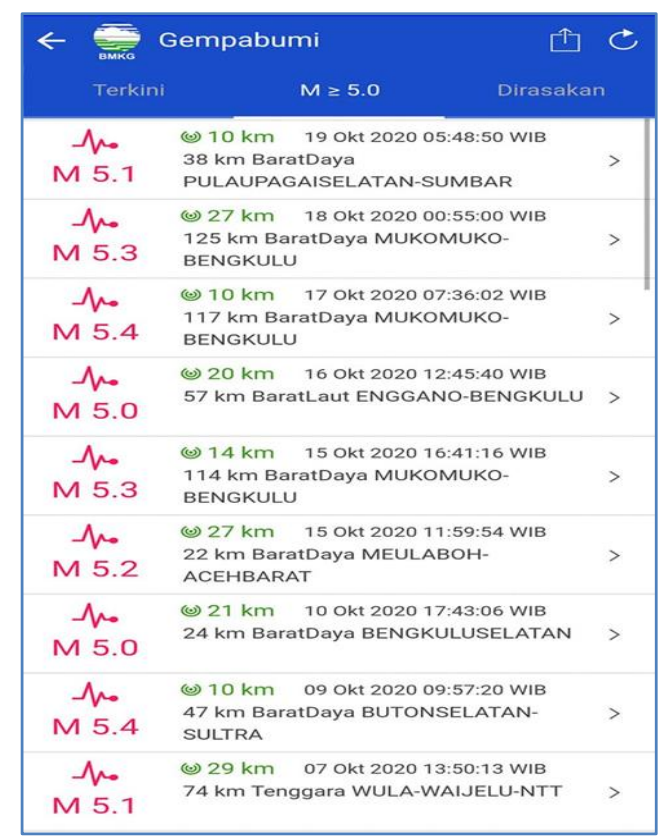

Gambar 3. Data aktivitas gempa bumi yang tercatat di situs BMKG (sumber: Badan Meteorologi dan Geofisika)

Berdasarkan Tabel 1 diketahui bahwa secara umum guru setuju bahwa Wawasan/pengetahuan terkait konten kebencanaan, pengetahuan mitigasi perlu dikuasai. Konten kebencanaan dan mitigasi perlu diberikan mulai dari jenjang sekolah. Hal ini karena Bengkulu merupakan daerah rawan bencana alam. Pengetahuan akan konten kebencanaan dan pengetahuan mitigasi yang baik akan memperngaruhi tindakan siswa sebagai bagian dalam masyarakat dalam menghadapi bencana alam baik sebelum bencana, saat terjadi bencana maupun setelah terjadinya bencana.

Berbagai bencana alam dapat dijelaskan menggunakan konsep sains misalnya bencana gempa dapat dijelaskan dengan konsep penjalaran gelombang. Jika dalam pembelajaran konsep gelombang disisipkan pengetahuan konten kebencanaan gempa sebagai aplikasi konsep gelombang dalam kehidupan sehari-hari maka siswa akan lebih memahami bagaimana proses terjadinya gempa serta kaakteristik bencana gempa itu sendiri. Dengan demikian siswa mendapatkan gambaran tidakan apa saja yang dapat mereka lakukan ketika bencana gempa bumi melanda, maupun tidakantindakan preventif untuk menghadapi bencana gempa bumi yang sering terjadi di Bengkulu. 
Dengan demikian konten sains sangat potensial untuk disisipkan dengan konten kebencanaan. Pendidikan mitigasi dapat diintegrasikan dalam pembelajaran konten sains. Pendidikan mitigasi berbasis kelas sangat potensial untuk membentuk generasi sadar mitigasi dari usia dini. Anak usia sekolah sangat potensial untuk menjadi agen of change dalam membentuk budaya masyarakat siaga bencana karena anak usia sekolah merupakan generasi muda yang akan menjadi penerus pembangunan serta menciptakan masyarakat yang memiliki kesadaran siaga bencana.

Berdasarkan hasil analisis tugas mandiri pada kegiatan pelatihan sesi kedua diketahui bahwa guru IPA sudah cukup baik dalam menganalisis kompetensi dasar untuk mengetahui potensi konsep sains untuk dapat disisipkan pendidikan mitigasi dan wawasan kebencanaan. Salah satu cuplikasi hasil tugas mandiri bidang IPA fisika yang dibuat oleh peserta pelatihan dapat dilihat pada Gambar 2 .

\begin{tabular}{|c|c|c|}
\hline $\begin{array}{l}\text { 3.9 } \text { Menganalisis besaran-besaran fisis } \\
\text { gelombang berjalan dan gelombang } \\
\text { stasioner pada berbagai kasus nyata }\end{array}$ & $\begin{array}{l}\text { 7.9 Melakukan percobaan gelombang berjalan } \\
\text { dan gelombang stasioner, beserta } \\
\text { presentasi hasil percobaan dan makna } \\
\text { fisisnya }\end{array}$ & $\begin{array}{l}\text { Pada konsep ini guru memberikan konsep } \\
\text { Pendidikan mitigasi bencana kepada siswa } \\
\text { mengenai gempa. Gempa adalah bencana } \\
\text { yang kerap terjadi di Indonesia khusus di } \\
\text { daerah yang berada di cincin api/ pertemuan } \\
\text { lempeng. Bencana ini adalah bencana yang } \\
\text { tidak di dapat diprediksi. Maka dari itu, } \\
\text { penting bagi siswa Pendidikan mitigasi sejak } \\
\text { sekolah. }\end{array}$ \\
\hline $\begin{array}{l}\text { 3.12Menganalisis gejala pemanasan global dan } \\
\text { dampaknya bagi kehidupan serta } \\
\text { lingkungan }\end{array}$ & $\begin{array}{l}\text { 4.12Mengajukan ide/gagasan penyelesaian } \\
\text { masalah pemanasan global sehubungan } \\
\text { dengan gejala dan dampaknya bagi } \\
\text { kehidupan serta lingkungan }\end{array}$ & $\begin{array}{l}\text { Pada konsep ini guru memberikan konsep } \\
\text { Pendidikan mitigasi bencana kepada kepada } \\
\text { siswa mengenai Pemanasan Global berupa } \\
\text { kemarau berkepanjangan. Kemarau } \\
\text { berkepanjangan menjadi masalah yang terjadi } \\
\text { akhir-akhir ini. Hal ini disebabkan oleh } \\
\text { aktivitas manusia yang membuat kadar } \\
\text { Karbon dioksida ke atmosfer bumi meningkat. } \\
\text { Penting bagi siswa untuk mengetahui hal ini } \\
\text { sebagai upaya mitigasi bencana } \\
\text { berkepanjangan. }\end{array}$ \\
\hline
\end{tabular}

\begin{tabular}{||l|l|l|}
\hline KOMPETENSI DASAR & KOMPETENSI DASAR & \\
\hline $\begin{array}{l}\text { 3.5 Menganalisis konsep energi, berbagai } \\
\text { sumber energi, dan perubahan } \\
\text { bentuk energi dalam kehidupan } \\
\text { sehari-hari termasuk fotosintesis }\end{array}$ & $\begin{array}{l}\text { 4.5 Menyajikan hasil percobaan } \\
\text { tentang perubahan bentuk energi, } \\
\text { termasuk fotosintesis }\end{array}$ & $\begin{array}{l}\text { Pada konsep ini guru dapat menjelaskan } \\
\text { perubahan energi terbarukan dan tidak } \\
\text { terbarukan. }\end{array}$ \\
\hline $\begin{array}{l}\text { 3.8 Menganalisis terjadinya pencemaran } \\
\text { lingkungan dan dampaknya bagi } \\
\text { ekosistem }\end{array}$ & $\begin{array}{l}\text { 4.8 Membuat tulisan tentang gagasan } \\
\text { penyelesaian masalah } \\
\text { pencemaran di lingkungannya } \\
\text { berdasarkan hasil pengamat }\end{array}$ & $\begin{array}{l}\text { Guru dapat memberikan pendidikan } \\
\text { mitigasi kepada siswa mengenai } \\
\text { pencemaran } \\
\text { lingkungan(air,tanah,udara) sehingga dapat } \\
\text { menyebabkan bencana seperti wabah } \\
\text { penyakit,banjir bandang, kebakaran hutan } \\
\text { yang mngakibatkan kabut asap dan juga } \\
\text { cara penanggulangannya, }\end{array}$ \\
\hline 3.9 Menganalisis perubahan iklim dan & \begin{tabular}{l} 
Pada konsep ini guru juga dapat mengajak \\
\hline
\end{tabular} \\
\hline
\end{tabular}

Gambar 4. Cuplikan hasil kerja tugas mandiri peserta pelatihan dalam membuat matrik analisis potensi integrasi pendidikan mitigasi

Berdasarkan Gambar 2 dapat diketahui bahwa peserta pelatihan yang merupakan guru IPA sudah dapat menganalisis kompetensi dasar yang ada didalam kurikulum K 13 
serta menganalisis peluang untuk menyisipkan konten kebencanaan dan pendidikan mitigasinya. Hal ini relevan dengan hasil penelitian terdahulu yang menyatakan bahwa pendidikan mitigasi sangat penting bahkan untuk di jenjang SD maupun pendidikan nonformal (Arifa, 2018; Suarmika dan Utama, 2017; Hayudityas, 2020)

Berdasarkan hasil pengamatan pada sesi pendampingan pembuatan tugas mandiri, guru menunjukkan antusias. Hasil analisis kualitatif tugas mandiri terlihat bahwa guru IPA peserta pelatihan telah mampu membuat matriks relevasi antara konten sains dengan konten kebencanaan. Sebagai contoh pada Gambar 2 terlihat guru IPA telah bisa mendeskripsikan konten kebencanaan yang relevan dalam pembelajaran konsep sains fisika khususnya konsep gelombang. Pada KD 3.8 di dalam Gambar 2 terlihat bahwa guru dapat mendeskripsikan konten kebencanaan yang sesuai untuk disisipkan dalam pembelajaran sains konsep pencemaran lingkungan. Analisis tugas madiri menunjukkan bahwa guru telah mampu menganalisis relevansi atau keterkaitan antara konten sains dan konten kebencanaan. Kegiatan PPM berikutnya data dilanjutkan dengan berbagai pelatihan sehingga guru dapat memiliki kompetensi untuk merancang kegiatan pembelajaran sains terintegrasi pendidikan mitigasi yang didasari dengan kemampuan menganalisis keterkaitan antara konten sains dan konten kebencanaan seperti pada kegiatan PPM yang telah dilaksanakan

\section{Kesimpulan}

Berdasarkan hasil analisis kegiatan pengabdian pada masyarakat yang telah dilaksanakan maka dapat disimpulkan bahwa integrasi pendidikan mitigasi sangat penting terutama untuk daerah rawan bencana alam seperti provinsi Bengkulu. Integrasi pendidikan mitigasi sangat potensial untuk dilakukan melalui pembelajaran sains mengingat karakter konsep sains yang berkaitan erat dengan berbagai fenomena alam termasuk fenomena kebencanaan. Guru IPA telah mampu menganalisis keterkaitan antara konten sains dan konten kebencanaan di dalam kompetensi dasar. Kemampuan ini menjadi dasar untuk dapat mengembangkan kompetensi berikutnya agar mampu secara mandiri merancang kegiatan pembelajaran sains terintegrasi pendidikan mitigasi bencana.

\section{Daftar Referensi}

Arifa, Fieka Nurul. (2018). Mitigasi Bencana pada Sektor Pendidikan Formal. Kajian Singkat Terhadap Isu Aktual dan Strategis. Vol. X, No. 20/II/Puslit/Oktober/2018 
Badan Nasional Penanggulangan Bencana. (2018). Laporan 4 BNBP. Jakarta: http://bnpb.cloud/dibi/laporan4

Farda N.M dan Prayudha.B. (2010).Manual SSOP Pengendalian Banjir dan Longsor: Yogyakarta.

Febriani.y, daruwati.i, hatikar. (2013). Analisis nilai peak ground acceleration dan indeks kerentanan seismik berdasarkan data mikroseismik pada daerah rawan gempabumi di kota Bengkulu. Jurnal Ilmiah Edu Research . 2013. Vol.2 No.2 Desember 2013

Hayudityas, Beatrix. (2020). Pentingnya Penerapan Pendidikan Mitigasi Bencana di Sekolah untuk Mengetahui Kesiapsiagaan Peserta Didik. Jurnal edukasi nonformal. Vol (1) No(2) page 94-102

Ibrahim, G., Subardjo. (2010). Pengetahuan Seismologi, Badan Meteorologi dan Geofisika

Irwanto, Yud (2015)i. Badan Informasi Geopasial. [online]. Tersedia: bakosurtanal.go.id

Mustari. Nilai Karakter: Refleksi Untuk Pendidikan Karakter. Yogyakarta: Laksbang Pressindo. 2011.

Permana R.C.E, Nasution.I.P, dan Gunawijaya.J. (2011). Kearifan lokal tentang mitigasi bencana pada masyarakat baduy. Makara, sosial humaniora, 2011.VOL. 15, NO. 1, JULI 2011: 67-76

Suarmika, Putu Eka dan Erdi Guna Utama (2017) Pendiaikan Mitigasi Bencana di sekolah Dasar (sebuah kajian analisis pedagogi). Jurnal Pendidikan Dasar Indonesia. Vol(2) No(2) Page $18-24$

Subiyantoro, I. (2010). Selayang Pandang tentang Bencana. Jurnal Dialog Penanggulangan Bencana, 1,

Sudibyakto. (2015). Kajian dan Mitigasi Bencana Gempa Bumi: Studi Kasus Gempa 